Received: $15 / 10 / 2019$

UDK: 373·3.091.3.046-021.64:51]:004.42 Geogebra

Professional paper

\title{
GEOGEBRA APPLIANCE IN THE TEACHING OF MATHEMATICS IN LOWER GRADES OF ELEMENTARY SCHOOL
}

\section{Suzana Tomaš}

Faculty of Humanities and Social Sciences University of Split suzana@ffst.hr

Josipa Jurić

Faculty of Humanities and Social Sciences University of Split

Mirna Paradžik

Faculty of Humanities and Social Sciences University of Split 


\section{ABSTRACT}

Technology has been imposed on today's students since their birth, them being surrounded by computers, tablets and other tools of the digital age. Mathematics is a teaching subject which represents the gratest obstacle to students in their schooling and prejudice against it has existed since the very beginning of schooling. Information and communication technology can make its learning much easier, both to students and teachers. The aim of the paper was to determine if there was a difference in the achievement of the students taught by contemporary GeoGebra classes and traditional classes. By conducting the research and interpreting the results, the GeoGebra program was found to have a significant role in learning of new contents in mathematics, and students have shown progress by working in the contemporary mode of GeoGebra program. It can be said that this program is very convenient in learning maths, especially in geometry, and the students were satisfied with their work in the program, what is confirmed with the results of the survey questionnaires on satisfaction issue.

Keywords: information communication technology, GeoGebra, mathematics, computer in teaching, contemporary teaching 


\section{INTRODUCTION}

Modern society requires new skills, abilities, attitudes, values, competences placing emphasis on the development of critical thinking, entreprise and problem solving. These requirements are reflected in the education system, where, as the curriculum emphasizes, it is planned to replace knowledge transfer by transfer of competencies. This kind of transformation extends to communication, understanding of natural and social phenomena, training of individuals for problem solving and continuous learning. The education system should prepare students to open same space for autonomous problem solving, decisions and conclusions making. Teaching content along with information and communication technology is not only a simple set up presentation but active learning must be accomplished. Such active learning will result in synergy of teaching content, and students, and information and communication technology. Information and communication technology make all educational materials available to all individuals eager of acquiring knowledge and skills. Speed of information and communication technology development is a challenge for teachers and institutions involved in the organization, management and financing of learning and teaching. In addition, the use of information and communication technologies in synergy with education affect the improvement of the quality of education and preparation of students for lifelong learning. The application of information and communication technology must follow methods and scenarios so that a quality teaching lesson can be accomplished. In order to make shaped teaching effective in an environment of information and communication technology students need to be motivated with well-designed teaching content.

Information and communication technology includes activities and equipment based on collecting, storing, processing, disseminating and sharing information in various forms such as sound, text, sign and image (Miroslav Krleža Lexicographic Institute).

All the above mentioned makes education in the modern society influenced by accelerated technological development and globalization process. The Basic National Curriculum Document (NOK, 2010) points out that in a society based on information and technology it is necessary to think critically about complex topics, interpret available information, analyze new situations and adapt to them, make informed decisions in everyday life, deal with different problems, apply technology effectively, and exchange ideas and opinions. Technology has been gradually infiltrated into almost every pore of society and human life, so using a computer can mean playing video games on your computer, browsing social net- 
works and other portals, but also learning. Whereas the traditional principles of education were based more on knowledge gaining than on a child, today's pedagogy is developing more and more, and with its development some new methods have been developed also, based on the development of creativity, giftedness and talent, and more and more attention is paid to educational process. It emphasizes the significant role of the teacher who through his personality and professionalism can significantly affect the progress and success of developing creativity and talents (Jensen, 2003). In the modern pedagogical process, one of the biggest challenges is to provide conditions that are suitable for proper teaching in the school so that the school can become a place that will properly prepare students for action in society. Therefore, it is necessary that the teaching is implemented in a variety of ways closer and more acceptable to students, taking into account their way of learning, but also the basic goals and tasks of education. The organization of the world moves from primarily vertical - command and control systems, to more horizontal - connection and collaboration. Previously mentioned has a significant impact on education so revolutionary changes in the area education are not only brought by new technologies, but first and foremost with new forms, such as e-learning and lifelong learning (Hutinski, Aurer, 2009). E-learning is closely related to educational technology that is not only a technical product but also a tool in the learning, teaching and learning process testing knowledge in the hands of a "good" teacher.

Children today, "digital natives" socialize significantly different from their parents. They spend hours playing video games, chatting on the Internet, watching television ...

The application of mathematics in various fields has greatly contributed to the development of modern society, what emphasizes its importance. Namely, it represents one of the factors of society's progress, so it is necessary to acquire mathematical literacy to develop life skills of an individual, even if the individual does not intend to take mathematical science more seriously. Teaching mathematics is a complex and demanding process, so it is essential to satisfy certain conditions to obtain its successful performance. In order to facilitate the understanding of mathematics, it is necessary to link it with other sciences. Since each student is an individual, it is advisable for teachers to use as many different teaching strategies, methods and forms of work as possible (Bognar, Matijević, 2002).

The syllabus is a school document that represents the specification of the curriculum. It prescribes the extent, depth and sequence of the teaching content of each school subject (Poljak,1984). The goal of mathematics is to acquire basic mathematical knowledge and literacy that serve to understand phenomena and 
regularities in nature and society and to develope the ability to solve various mathematical problems (Curriculum for elementary school, 2006).

"Concerning teaching mathematics a pocket calculator was twenty years ago in the same situation as desktops and laptops are today. No doubt one day teaching will be unthinkable without much wider use of computers" (Erjavec, 2010, 15). Proper use of technology in teaching make students stay focused longer, and learn in a more interesting way for them, which is familiar and accessible to them given the time they were born. By learning of the contents in mathematics, students experiment and discover different ways of coming to a solution. Inclusion of a computer in the learning process and the use of adequate programs allow students to visually identify the solution to the problem.

Mathematics as a teaching subject or the content of it is very compatible with working / learning on a computer because students can experiment and discover.

Besides the above mentioned facts, also the fact that information and communication technology is developing rapidly and unstoppably has a great impact on the whole way of living, and therefore learning. Learning is an integral part of every person's life, and today we are looking for programs that will make learning fun. If we use that program to advance the learning process of the Maths syllabus, we are on track of finding ways of teaching that make it easier for students to gain knowledge of complex content. Therefore, we describe the implementation of the GeoGebra program in this paper and state positive attitudes of the students after applying this program.

"GeoGebra is an open source computer program applicable at all levels of mathematical education, both for teaching and for independent learning " (Šuljić, 2010, 28). It is an interactive geometric program that simultaneously offers algebraic input (Tomić, 2013). Use of the program is aimed at education of the students and encourages curiosity, the need for experimentation; places emphasis on the research aspect of learning and strategy of coming to the solution. "Apart from the greater curiosity when learning, this strategy leads to a more lasting knowledge of the students who in this way themselves systematize the information adopted "(Misurac, Juric, 2019, 81). The program has the ability of observations of mathematical objects from three points of view: graphical representation, algebraic representation and tabular representation. All displays of a single object are dynamically linked and will change automatically if any display changes, regardless of how the object was originally created (Tomić, 2013). The program excels user-friendly and easyto-use interface with clear functionality easier to work with and the tools managing. As one of the important issues we must point out that the program is free of charge and does not have to be installed on your computer, but it can be done online what enables practice and repeatition outside of school. 
Dijanić (2017) suggested a learning model based on constructive learning theory and Polyna's heuristic strategy for solving mathematical problems in her work Computer-guided learning by discovery using GeoGebra. Teachers who used the model noted with students to have a better understanding of mathematical concepts and the great potential of computers to help with conducting researchoriented teaching.

Tolić, Jukić and Josipović (2015) observed Multimedia learning and evaluation of maths pinboards on the example of GeoGebra. The study involved 420 students of the first grades of the secondary vocational school of the County of Split and Dalmatia. It showed that the frequent use of computer strategies and multimedia didactics can significantly affect the learning process. The results of the research show that the use of GeoGebra in teaching makes the adopting of the Maths contents easier. This also increases the motivation to learn the content itself, and also contributes to the development of digital competencies, both in students and teachers.

Scientists Saha, Ayub, and Tarmizic (2010) from the Institute of Mathematical Researches and the Teacher's College in Malaysia at the International Conference on Researches and Mathematics education (ICMER 2010) presented their work called The effects of GeoGebra on mathematics achievement: Enlightening coordinate geometry learning. The study involved 53 students, 27 of them worked geometry in the coordinate system in GeoGebra, while the rest were taught traditionally. The results showed a significant difference in achievement in favor of the group that worked on a computer with the help of a program.

Furthermore, Dogan and Icel (2011) from the Teacher's College in Turkey published an article The role of dynamic geometry software in the learning process: GeoGebra example about triangles in which they observed two groups of 20 students each. One group worked the entire lesson about the Triangle with the help of Geogebra and it showed up that this group had better results in the posttest. Also, the test was repeated after some time and the results revealed that the GeoGebra group had again written it more successfully thereby bringing to conclusion that their knowledge is more permanent. Researchers who did the research and worked with students commented that those who worked in the program were far more motivated to work.

"Technology has given maths a new chance if specialized computer programs are used. GeoGebra is certainly one of those shortlisted programs. When it comes to the creation of digital educational materials for e-learning, then it is free to say how Geogebra is limited only by the creativity of teachers "(Šuljić, 2010, 30).

The mathematics lesson when assisted by interactive digital materials that we call applets can be very effectively organized in research-oriented teaching but it 
has to meet certain prerequisites, preparation for the lesson being the most important. That means teacher mathematics needs to find the appropriate material that students will work on or create themselves. GeoGebra makes it easy to create or modify existing applets. Applets mainly they contain several step-by-step instructions that help students guide their assignments. By working on applets students experiment and draw conclusions independently to build their own knowledge, and carefully selected tasks lead them to their final destination with minimal risk of failure (Bjelanović Dijanić, 2012). With this guided learning discovery approach, students get to know each other mathematical concepts and laws at a higher level than if the teacher presented them finished facts.

GeoGebra can be applied to the following mathematical contents of a geometric nature:

- 1st grade: bodies in space, flat and curved surfaces, line types, point, geometric characters;

- 2nd grade: length, sides of squares, rectangles and triangles;

- 3rd grade: plane, directions and their relations, half-length and length as parts of a straight line, fluid volume;

- 4th grade: angle, types of angles, types of triangles with respect to sides, right triangle, range of triangle, rectangle and square, range of rectangle and square, measurement of surfaces, surface of rectangles and squares, circle, circle.

\section{METHODS}

The research in this paper was conducted in a group of the second grade primary school students. The one-group experiment method was used, the experimental factors whose effect we examined were entered in the same group. Therefore, the experimental factor is the application of GeoGebra. In order to check the effectiveness of this program, one class was held over two teaching days.

The math's classes on the topic of Length as a two-point junction was held on the first day in the traditional teaching method. On the second day, classes were held with the help of GeoGebra in a computer classroom on the subject Sides of Squares, Rectangles, and Triangles.

Respondents are seventeen students $(\mathrm{N}=17)$ of the second grade of elementary school in Split.

The tasks of the research are: to design teaching contents for the traditional teaching of maths classes on the topic of Length as a junction of two points, to design the teaching content for thr topic Sides of squares, rectangles and triangles 
in the GeoGebra program, determine students' foreknowledge, determine their knowledge after learning it traditionally and in the GeoGebra program, compare the results of the initial and final test after studying it in the Geogebra program and traditionally and examine student's satisfaction after applying GeoGebra.

The problem we are researching in this paper is to test the effectiveness of GeoGebra in teaching mathematics. The aim of the research is to determine if there is a difference in student's achievement after learning teaching topics Sides of squares, rectangles and triangles in GeoGebra and after learning teaching topics Length as a two-point junction in the traditional way (without GeoGebra). In addition, the goal is also to determine student's satisfaction by studying in GeoGebra.

In accordance with the set goal and tasks of the research, we start from the following hypothesis: Students showed better results in the knowledge and understanding of the geometric contents of maths in the second grade of elementary school with the help of the GeoGebra program.

Instruments that examined the initial and final state of knowledge in this research included objective type tasks. The sorts of objective type tasks are: short tasks answers, complements and draws. The content covered in the test was the content of the teaching topic, therefore the students took two separate tests. The tests were repeated after learning the teaching content at two different ways.

Before learning both teaching topics, students wrote the initial test, after the initial test students learned teaching content in two different ways traditionally and with the help of GeoGebra program and then wrote the final test to verify content adoption.

The questionnaire was conducted at the end of the survey. The questionnaire consisted of five statements to which the students responded by choosing three different grades: I agree, neither agree nor disagree and I do not agree.

\section{RESULTS AND DISCUSSION}

After analyzing the results of the initial test on the first and the second day, it was found that there was no statistically significant difference in the initial examination between the objective topics (Square's, rectangle's and triangle's sides, and Length as a junction of dots) (table 1 ).

Table 1. T-test of initial testing of students in topics Square's, rectangle's and triangle's sides, and Length as a junction of dots

\begin{tabular}{lcccccc}
\hline Variables & $\mathrm{AS}$ & $\mathrm{SD}$ & $\mathrm{N}$ & $\mathrm{T}$ & $\mathrm{df}$ & $\mathrm{p}$ \\
\hline Square's, rectangle's and triangle's sides & 3.05 & 1.20 & & & & \\
\hline Length as a junction of dots & 3.76 & 1.95 & 17 & 1.59 & 16 & 0.13 \\
\hline
\end{tabular}

${ }^{*} p<.05000, \mathrm{AS}$ - arithmetical mean, SD - standard deviation 
On degree of freedom (df) 16, level of significance on 0,05 amounts the value of t test as 2.12. After testing the statistical significance between the initial testing in two different teaching subjects, we found that the obtained t test value (1.59) is less than the limit value. Based on that, $1.59<2.12$ we conclude that between the initial testing for the teaching subjects Square's, rectangle's and triangle's sides and Length as a junction of dots doesn't exist significant statistical difference.

Table 2. T-test of initial and final testing of students - subject Square's, rectangle's and triangle's sides, GeoGebra learning

\begin{tabular}{lcccccc}
\hline Variables & AS & SD & $\mathrm{N}$ & $\mathrm{t}$ & $\mathrm{df}$ & $\mathrm{p}$ \\
\hline initial testing & 3.06 & 1.19 & & & & \\
\hline final testing & 9.41 & 4.14 & 17 & 7.30 & 16 & 0.02 \\
\hline
\end{tabular}

${ }^{*} p<.05000, A S$ - arithmetic mean, $S D$ - standard deviation

On degree of freedom (df) 16 level border value of $t$ test is 2.12 , however $t$ test result in the difference of the obtained results of initial and final testing is 7.30 (table 2). This result indicates that there is a statistically significant difference between initial and final testing in favor of final testing. That is, after learning with Geogebra, students showed very good results in the final test.

Table 3. T-test of initial and final testing of students - subject Length as a junction of dots, traditional learning

\begin{tabular}{lcccccc}
\hline Variables & AS & SD & $\mathrm{N}$ & $\mathrm{t}$ & $\mathrm{df}$ & $\mathrm{p}$ \\
\hline initial testing & 3.76 & 1.95 & & & & \\
\hline final testing & 20.94 & 4.70 & 17 & 15.09 & 16 & 0.00 \\
\hline
\end{tabular}

${ }^{*} p<.05000, A S$ - arithmetic mean, SD - standard deviation

Obtained t value on degree of freeedom (df) 16 amounts 15.09, and it is bigger than border t value (2.12). According the results we conclude that there is a statistically significant difference between the initial and the final testing of knowledge after the traditonal learning of the class subject Length as a junction of dots.

The set hypothesis states: Students showed better results in the knowledge and understanding of geometric content of mathematics in the second grade of elementary school with the help of GeoGebra program. 
Table 4. T-test of the difference between the final and initial testing of students after traditional learning and GeoGebra

\begin{tabular}{lccccccccc}
\hline Variable & AS 1 & AS2 & SD1 & SD2 & N1 & N2 & t & df & p \\
\hline $\begin{array}{l}\text { final - initial testing traditional classes } \\
\text { (1) }\end{array}$ & & & & & & & & & \\
final - initial testing & 6.35 & 17.18 & 3.58 & 4.69 & 17 & 17 & 7.55 & 32 & 0.29 \\
GeoGebra classes (2) & & & & & & & & & \\
\hline
\end{tabular}

* $p<.05000, \mathrm{AS}$ - arithmetic mean, SD - standard deviation

By comparing the results of the difference between final and initial testing, we accepted the set hypothesis because at a significance level of 0.05 and degree of freedom 32 the limit of the $t$ test is 2.04 . The corresponding value of the $t$ test is 7.55 and shows statistical significance in favor of the results obtained in the difference between the two tests after learning in GeoGebra.

Furthermore we were interested in the students' satisfaction after learning at GeoGebra. Student satisfaction was determined in a questionnaire that included seven statements which students answered making the choice of one of the three levels of agreement, or disagreement (agree, neither agree / nor disagree, disagree). In addition, respondents chose one of the offered evaluations (from 1 to 5) to GeoGebra program.

The obtained results of the questionnaire are as follows:

- $100 \%$ of the students agree with the statement Drawing inGeoGebra made me feel satisfied.

- $82 \%$ of the students would like to draw in Geogebra

- $70 \%$ of the students claims that the tasks in Geogebri aren't difficult

- $52 \%$ of the students consider that their teacher should use Geogebra in further teaching.

- $65 \%$ of the students evaluate GeoGebra with an exellent mark

- $35 \%$ of the students evaluate GeoGebra with a very good mark.

Thus, the analysis of students' answers revealed a high degree of satisfaction with learning in GeoGebra. In this way, students learn at their own pace, have the ability to repeat teaching content, visualize mathematical content, have background information, and, according to their claims, find solutions easier. This view of the application of Geogebra in teaching was also confirmed by Boo Jia Yi and Kwan Eu Leong (2016) after applying Geogebra in teaching with students. After examining the opinions of students, who in $90 \%$ agreed to better understand the concepts in geometry and 95\% want to use GeoGebra more often, they concluded that the application of this program in the learning and teaching process can enhance geometry knowledge in elementary students .

In addition Shadaan and Leong. (2014) state that the analyzed features of GeoGebra enable the integration of the program into the curriculum in Lithuania. 
As a result, justifying the results of the research described in this paper, we also cite an action research that describes the positive results and attitudes of students towards GeoGebra, all students have worked hard, used creativity, discovered using intellectual power and are learning how to find results that they need it, there is an increase in students' cooperation in learning and motivation is better (Bjelanović, Dijanić 2012).

The research results (Dijanić, Trupćević, 2016) with 703 students of sixth, seventh and eighth grades from twelve elementary schools in Croatia studied at GeoGebra. The results of this study confirmed the positive effects obtained in our study.

The above studies confirm that GeoGebra is a good program for the learning and teaching process in school, especially for mathematics. The program is not only intended for upper elementary school students, but the program can also be applied to students from the first to the fourth grade of primary school, as confirmed by this research. In addition, GeoGebra should be promoted as a dynamic program that enables students to improve their understanding of mathematical concepts (Ogan, Ibibo, 2018). Given that GeoGebra is a free program, it should be promoted among classroom teachers in order to bring students closer to the abstract world of mathematics.

\section{CONCLUSION}

Today's society and the way of life are very fast-paced, so we need to approach to teaching of our students accordingly. Some of the features of contemporary teaching are learning by discovering, autonomous problem solving, divergent and creative thinking (De Zan, 2005).

Representation of information and communication technology, and therefore computer programs, is present in all aspects of life. Today's society is marked by the prefix computer's (Digital). Well designed teaching content with quality software support can enhance the process of learning, teaching and testing knowledge. Work, learning and fun today are unimaginable without applications of information and communication technology. All the mentioned above is the reason for the introduction of information and communication technologies into the teaching process, thereat considering only the relevant software that will enhance the student's learning process and teacher's teaching process.

The teachers who have used GeoGebra in mathematics teaching so far have positive experiences. GeoGebra is a familiar program to teachers, but they have a problem using it. They fear independent work in the program. The computer 
in the classroom encourages motivation to learn and seeks active participation. Students learn independently and determine their own pace. It showed that the students enjoy the work on the computer and that this work favors the learning of maths content. GeoGebra is convincingly one of the best programs to use in teaching today and especially in teaching scientific subjects such as mathematics.

Getting started with GeoGebra and similar programs is extremely difficult, as it is with everything you are meeting for the first time, and a number of researches that have been conducted to testify this. Workshops for teachers aiming to help and educated them are constantly organized who then with their persistence and work can make progress that will make it easier for children to learn and make it all interesting. Any person who has had any computer science education can learn to use programs of this type with great effort and will. GeoGebra is a program that has really good instructions and explanations for how it works, plus we have YouTube where we can watch various videos about the program.

This program offers a myriad of teaching opportunities and makes easier for students to understand some geometric concepts, such as making it easier for teachers to convey the knowledge they have difficulty to understand when on paper. That's how some students discovered new ways of drawing triangles during the lesson, which is further evidence of how interesting this is for them because when they solve a problem they don't wait passively, but research the program themselves.

The research confirmed the quality of work in the GeoGebra program to work on in the field of geometry in the subject Mathematics, even with the second grade elementary schools students. We have also seen that the use of information and communication technology in the teaching has a positive impact on students, they are more motivated to work and come up with answers independently.

Technology is becoming more and more accessible to today's students, even from a young age they have been taught how to use it and have no problem using it in class. Traditional teaching becomes less interesting to them and they look for a lesson that will further interest and engage them in work. For this reason, it is a positive thing to include digital tools because they allow students to work independent research and motivate them to work and learn. 


\section{REFERENCES}

1. Bjelanović Dijanić, Ž. (2012). Računalo u istraživačkom radu učenika u nastavi matematike. Napredak: časopis za pedagogijsku teoriju i praksu, 153 (2): 203-218.

2. Bognar, L., Matijević, M. (2002). Didaktika. Zagreb: Školska knjiga.

3. Boo, J. Y., Leon, K. E. (2016). Teaching and Learning of Geometry in Primary School Using GeoGebra. Proceedings of the 21st Asian Technology Conference in Mathematics: 289-300.

4. Charles-Ogan, G., Gladys Ibibo. (2018). GeoGebra: A Technological Soft Ware for Teaching and Learning of Calculus in Nigerian Schools. American Journal of Applied Mathematics and Statistics, 6 (3): 115-120.

5. De Zan, I. (2005). Metodika nastave prirode i društva. Zagreb: Školska knjiga.

6. Dijanić Ž., Trupčević G., (2016). The impact of using GeoGebra interactive applets on conceptual and procedural knowledge /on line/.

7. https://bib.irb.hr/datoteka/878910.Dijanic_Trupcevic_Impact_GeoGebra_knowledge_finish.pdf $(5 / 9 / 2019)$

8. Dijanić, Ž. (2017). Računalno vođeno učenje otkrivanjem uporabom GeoGebre. U: Zbornik radova 19. CARNetova korisnička konferencija CUC 2017. "Povezani znanjem (...25 godina)", Dubrovnik, 2017 (1-8).

9. Dogran, M., Icel, R. (2011). The role of dynamic geometry software in the process of learning: GeoGebra example about triangles. International Journal of Human Science, 8 (1): 1441-1458.

10. Erjavec, Z. (2010). E-motivacija i matematika. In Matematika i e-učenje., Dubrovnik, 2010 (1316). Varaždin: TIVA Tiskara Varaždin.

11. Hutinski, Ž., Aurer, B. (2009). Informacijska i komunikacijska tehnologija u obrazovanju: stanje i perspektive. Informatologia, 42 (4): 265-272.

12. Jensen, E. (2003). Super-nastava: nastavne strategije za kvalitetnu školu i uspješno učenje. Zagreb: Educa.

13. Leksikografski zavod Miroslav Krleža. /on line/. http://www.enciklopedija.hr/ (10/9/2019)

14. Mišurac, I., Jurić, J. (2019). Učenje otkrivanjem na primjeru upoznavanja Talesova poučka. U: Knjiga sažetaka Prozor u Svijet obrazovanja, nauke i mladih, Sarajevo, 2019 (18). Sarajevo: Pedagoški fakultet Sarajevo.

15. Nacionalni okvirni kurikulum za predškolski odgoj i obrazovanje te opće obvezno i srednjoškolsko obrazovanje (2010). /on line/.

16. https://www.azoo.hr/images/stories/dokumenti/Nacionalni_okvirni_kurikulum.pdf (10/9/2019)

17. Nastavni plan i program za osnovnu školu (2006). /on line/.

18. https://www.azoo.hr/images/AZOO/Ravnatelji/RM/Nastavni_plan_i_program_za_osnovnu_ skolu_-_MZOS_2006_pdf (7/9/2019)

19. Paradžik, M. (2017). /on line/.

20. https://repozitorij.svkst.unist.hr/islandora/object/ffst\%3A1148 (1/7/2019)

21. Poljak, V. (1984). Didaktika. Zagreb : Školska knjiga. 
22. Prensky, M., (2005). Digitalni urođenici, digitalne pridošlice: Razmišljaju li doista drugačije?, Edupoint časopis. /on line/.

23. http://edupoint.carnet.hr/casopis/32/clanci/2.html (5/9/2019)

24. Proleksis enciklopedija. /on line/.

25. http://proleksis.lzmk.hr/29882/?fbclid=IwAR1kQKmlapStTu_HNPb3R2JXkdJX_6JMyxQHgd917ef8bv4ez9zB1pR_Q4 (7/9/2019)

26. Sahaa, R., Ayub, A., Tarmizi, R. (2010). The effects of GeoGebra on Mathematics achievement: Enlightening coordinate geometry learninig. Procedia Social and Behavioral Science, 8: 686-693.

27. Shadaan, P., Leong, K. E. (2014). Effectiveness of using GeoGebra on Students' Understanding in learning Circles. The Malaysian online Journal of Educational Technology(MOJET), 1 (4): 1-11.

28. Šuljić, Š. (2010). GeoGebra-alat za e-učenje. U: Matematika i e-učenje., Dubrovnik, 2010 (28-31). Varaždin: TIVA Tiskara Varaždin.

29. Tolić, M., Jukić, R., Josipović, V. (2015). Multimedijsko učenje i vrednovanje matematičkih panoa na primjeru GeoGebre. Medijska istraživanja: znanstveno-stručni časopis za novinarstvo i medije, 21 (2): 125-155.

30. Tomić, M. (2013), Matematički softver u nastavi matematike u hrvatskim školama - pregled GeoGebre i Geometer's Sketchpada. Croatian Journal of Education : Hrvatski časopis za odgoj i obrazovanje, 15 (1): 197-208.

31. Zilinskiene, I. (2014). Use of GeoGebra in primary math education: a theoretical approach. Proceedings of the Lithuanian Mathematical Society, 55: 73-78. 


\section{PRIMJENA GEOGEBRE U NASTAVI MATEMATIKE NIŽIH RAZEDA OSNOVNE ŠKOLE}

\section{SAŽETAK}

Današnjim učenicima je od samog rođenja nametnuta tehnologija, okruženi su računalima, tabletima i ostalim alatima digitalnog doba. Matematika je nastavni predmet koji učenicima predstavlja najviše prepreka u njihovom školovanju te predrasude prema istome postoje već od samog početka školovanja. Informacijska i komunikacijska tehnologija može znatno olakšati učenje ovog predmeta, kako učenicima tako i učiteljima.

Cilj istraživanja bio je utvrditi postoji li razlika u postignućima učenika podučavanim suvremenom nastavom u programu GeoGebra i nastavom održanom na tradicionalan način. Provedbom istraživanja i interpretacijom rezultata utvrđeno je da program GeoGebra ima značajnu ulogu u učenju novih sadržaja matematike te su učenici pokazali napredak radom na suvremeni način u programu GeoGebra. Može se reći da ovaj program matematici izvrsno odgovara, pogotovo u geometriji, te su učenici bili zadovoljni radom u programu što smo potvrdili rezultatima anketnog upitnika zadovoljstva.

Ključne riječi: informacijsko-komunikacijska tehnologija, GeoGebra, matematika, računalo u nastavi, suvremena nastava 


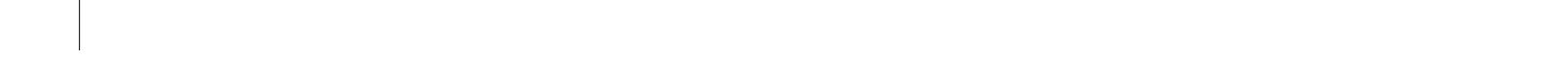




\section{AUTHOR GUIDELINES}

The scientific journal "METODIČKI OBZORI” (Methodical Horizons) publishes original scientific papers, preliminary communications, review papers, professional papers and book reviews indirectly or directly dealing with educational issues. Only previously unpublished papers will be published.

The journal publishes scientific and professional papers in the area of pedagogy, psychology, teaching methodology, sociology, education and rehabilitation sciences, philosophy, but also other scientific areas in which the topic of the paper is related to education.

After two positive reviews (one of which is international and the other national), the papers are published in English, while the special issues are in Croatian. The members of the editorial board are international and national scientists and experts in the field of social sciences and humanities. The editorial board of the journal enables scholars and educators to publish papers resulting from scientific, theoretical, empirical and practical research and studies.

The papers are to be submitted in digital form only, at the journal e-mail address mobzori@unipu.hr; metodicki.obzori.unipu@gmail.com.

Scientific papers should have between 22,000 and 40,000 characters with spaces, while professional papers and book reviews should have up to 12,000 characters with spaces. The paper is submitted in the following format: A4 size, all margins $2 \mathrm{~cm}$, font size 12 pt. Times New Roman, single spacing (1.0). The words should not be underlined, but italics should be used. Submitted papers and appertaining attachments are not to be returned.

The title of the paper should be clear, centred, capitalized, Times New Roman, font size 14 pt., bold. The title should include information on the author(s): first and last name, academic degree, name of the institution where the author(s) works and contact email, font size 12 pt. Times New Roman, single spacing (1.0).

The manuscript must contain an abstract (600 to 1,000 characters with spaces) indicating the purpose of the paper, theoretical and methodological starting 
points, the most important (main) results and conclusion, Times New Roman, font size 12 pt. the Abstract subtitle, font size 12 pt., bold. At the end of the abstract, up to five keywords should be listed under "Keywords" that are expertly and scientifically relevant to the issue being addressed.

The abstract, together with the keywords and title of the paper, is to be submitted in English, Croatian and Italian, in the formats indicated. If the paper is written in another language (for example, German), then the abstract is also provided in that language. Abstracts and keywords in the language in which the paper has been written are placed at the beginning of the paper, while the title of the paper, abstract and keywords in other languages are placed at the end of the paper, after the literature.

The text of a scientific paper principally consists of the following sections: Introduction; Methods; Results and Discussion; Conclusion. Non-numbered subtitles should be written in Times New Roman, 12 pt., bold, with one line of empty space above the subtitles.

Graphic attachments (figures, drawings, tables, charts) should be clear, sharp and clearly visible, in black, white and grey and appear in a separate document. The text of the paper should indicate where it will be inserted in the publication (Times New Roman, font size 10 pt.). Each graphic attachment and table should have a title and be numbered sequentially (e.g.: Table 1.) associated with the text. The table title is located above the table and the title of the image or chart goes below them. Title, for example: Table 1., Times New Roman, 11 pt., bold, while the continuation of the title is the same without bold.

The acceptance of categorized papers for publication obliges the author(s) not to publish the same article elsewhere until the review process is completed.

Whenever a text is referenced in a work, the source should be cited in the text, not in the notes, for example: (Tatković et al., 2015) or if it is a citation (Matijević, 2001, 51). If there are two authors, both should be mentioned (Radetić-Paić, Blažević, 2018), and if there are more than one, then surname of the first author and associates (Klapan et al., 2001).

The footnotes should be used solely for commenting or supplementing, i.e. clarifying what has been said in the text. All works that are referenced or cited should be listed at the end of the paper in alphabetical order by the author's surname, for example:

\section{Books:}

1. Tatković, N. Močinić, S. (2012). Učitelj za društvo znanja. Pedagogijske i tehnologijske paradigme bolonjskog procesa. Pula: Sveučilište Jurja Dobrile u Puli. 
2. Šuran, F. (2012). Giambattista Vico i „Nova znanost“. Pula: Sveučilište Jurja Dobrile u Puli.

3. Radetić-Paić, M., Ružić-Baf, M., Zuliani Đ. (2011). Poremećaji nedovoljno kontroliranog ponašanja sa psihološkog, socijalnopedagoškog i komunikacisjkog aspekta. Zagreb: Učiteljski fakultet Sveučilišta u Zagrebu.

\section{Journals:}

1. Blažević, I., Radetić-Paić, M., Babić, V. (2012). Relations between behavioural disorders self-assessment and free time sports ' practice in school-aged children. Science, Movement and Health, XII (2): 485-491.

2. Šuran, F. (2010). Vicova „Nova znanost“ između filozofije i moderne znanosti. Filozofska istraživanja, 117-118 (1-2): 160-181.

\section{Articles in proceedings:}

1. Ružić-Baf, M., Radetić-Paić, M. (2011). Prezentacija multimedijskih sadržaja, pamćenje informacija i pažnja. U M. Plenković (ur.), Zbornik radova međunarodne konferencije Društvo i tehnologija, Zagreb, 2011 (178-183). Zagreb: Hrvatsko komunikološko društvo \& Nonacom.

\section{Paragraphs in books:}

1. Antekolović, Lj., Blažević, I., Mejovšek, M., Čoh, M (2008). Longitudinal follow-up of kinematic parameters in high jump. In M. Čoh (Ed.), Biomechanical diagnostic methods in athletic training (pp. 63-76). Ljubljana: University of Ljubljana, Faculty of sport.

\section{Electronic sources:}

1. 1. U.S. Department of Education. (2007). Title IX: 25 Years of progress /on line/. www.ed.gov/pubs/TitleIX/title.htm (15/4/2009)

If more works of a single author are cited, than they should be arranged chronologically and if there are more works of the same author of the same year, the first is listed as (2005a), the second as (2005b), etc.

"METODICKI OBZORI" (Methodocal Horizons) will be published at least once a year, and some issues will be published thematically as agreed by the editorial board.

\section{Categorization of papers:}

An original scientific paper contains original theoretical and practical research results. 
A preliminary communication contains one or more new scientific data, but without sufficient details that might enable verification as in original scientific works. It may contain results of an experimental research, that is, the research which is still underway, the results of which, due to their relevance, need to be published as soon as possible.

A review paper contains a complete review of conditions and tendencies in the development of a certain theoretical field, methodology or application with a critical view or assessment. The cited references have to be sufficiently whole to enable a quality insight and participation in the presented area.

Other works - reviews, representations, news etc. - that are impossible to be categorized as above will not be subject to categorization.

The Editorial Board of Metodički obzori (Methodical Horizons) and the editor in chief retain the right to select the papers for publication, as well as to define the sequence of publishing the reviewed papers. 